\title{
Implementation of Accrual Accounting : Evidence from Public Sector Accounting Department officers in Malaysia
}

\author{
Nor Aishah Mohd Ali ${ }^{1}$, Zaharah Abdullah' ${ }^{2}$, Rozaiha Ab Majid ${ }^{3}$, Siti Aisyah Basri ${ }^{4}$ \\ and Siti Fatimah Noor Minhad ${ }^{5}$ \\ \{aishah72@uitm.edu.my ${ }^{1}$, zaharah@uitm.edu.my ${ }^{2}$, rozaihamajid@uitm.edu.my ${ }^{3}$, \\ Aisyah936@uitm.edu.my ${ }^{4}$, sitifatim@uitm.edu.my ${ }^{5}$ \}
}

Faculty of Accountancy, Universiti Teknologi MARA Melaka campus, Malaysia

\begin{abstract}
Understanding accounting standard in crucial for those bestowed with responsibility to record and prepare the required accounts and financial statements. Whilst the accountability to prepare those accounts and financial statement lies on the management, this task is responsibled to the accounts department of the organization. The importance of recording and reporting is equally crucial to the public sector as well as the private sector if not more. As the government agencies entities are subject to the public scrunity even though their performance if not measured by increase in the net profit, however, the way they manage the public fund is of prime concern. The Malaysian public sector agencies is in the transition of changing from cash accounting to accrual accounting in their recording and reporting of their accounts. A preliminary study has been performed to postulate the understanding of the accounting officers of the new method. To achieve the objective of the study, a questionnaire was distributed to the account staffs of local government agencies within the state of Melaka. A total of 131 questionaires were gathered from 16 state government agencies. The findings shows mixed responses have been received from the different level of positions for the change of the method as well as their understanding over the accrual accounting method.
\end{abstract}

Keywords: Public sector, understanding, accrual accounting.

\section{Introduction}

The Malaysian government has adopted and developed various accounting systems in the past years by focusing on efforts to strengthen efficient planning utilisation and control of public financial resources and assets. The procedures and practices of accounting and reporting are governed by a set of rules, which provides provisions of financial, budgeting, accounting and auditing aspects of the government [1]. 
Cash-based accounting system, a method where revenue and expenses are recognised when payment are made or received are being used in Malaysia since independent. Modified cash-based accounting are than adopted in 1974 [2]. Modified cash-based are an hybrid methods that combines features of both the cash basis and accrual basis [1]. Accrual accounting is an accounting technique where transactions and economic events are recorded and reported when they occur, regardless of when cash transactions occur [3]. The adoption of accrual-based accounting in public sector is not new. Governments of several countries have implemented accrual accounting, including United Kingdom, Canada, Australia, The Netherland, Sri Lanka and Indonesia [4]. New Zealand and Australia are frequently cited to have the most comprehensive accrual accounting adoption than other countries [5].

To meet the challenges of being a fully developed country by 2020, Malaysia introduced the Government Tranformation Programme (GTP) and New Economic Model (NEM) in 2010. Accrual-based accounting in the public sector is listed as one of the key policies measures in NEM in an effort to improve public sector finance practices [6]. The decision to move from cash-based accounting to accrual-based accounting is triggered largely by the growing demand for a greater transparancy and better performances of the government sector and the companies controlled by the government [7].

The adoption of accrual accounting has been approved by the Prime Minister on May 2011, where the Accountants General Department (AGD) was appointed as the head of the agency that is responsible for the implementation of accrual accounting [8]. The Federal Government of Malaysia is set to adopt full accrual-based accounting for financial reporting by 1 January 2015 [9]. However, the implementation of accrual-based accounting has been postponed twice. Initially, the implementation was postponed from 2015 to 2017 and further postponed to 2018 [10]. After a few false start, the accrual-based accounting will be a fait accompli by 2021 [11]. The postponements of the transition, to some extent indicates that the government is not yet ready to implement accrual-based accounting [10].

In light to the above issue, this paper is a preliminary study to highlight the level of understandability within the government officers towards the implementation of accrual-based accounting.

\section{Literature Review}

\subsection{Adoption of Accrual accounting in Malaysia and other countries}

Accrual accounting is adopted for engendering the benefits of improved awareness of the financial impacts of their decisions, improved asset management, and improved risk assessment, the integration of the reporting with the budget process was a prerequisite [12]. In addition, it is a well-established and comprehensive information system that illustrates the financial consequences of activities and extensively accepted by standard setter around the world [13]. Therefore, the application of accrual accounting through its reliability and 
consistency reporting in the government financial system is considered crucial to increase the accountability of government and fulfilling the public needs. However, the preparation of financial statement based on accrual accounting takes a lot of trainings and study programs that may preoccupies the government officials. This in turn leads to concern over the public welfare is being ignored at the same time [14].

In Nepal, the reason for the adoption of accrual accounting is the cash basis accounting was claimed to be inadequate in terms of both identifying the full costs of development projects that were funded by international organizations and development partners and demonstrating their results and outputs [15]. Some Nepalese administrators alluded to their own willingness and expertise as the primary motivational factor between the adoption of new reporting formats compatible with the International Public Sector Accounting Standard (IPSAS).

There are many factors that contribute to the effective implementation of accrual accounting reforms. Pressure from donors, auditors and also the strain faced by the employees due to rigorous training, shape the design of the quality of accrual accounting-based administration [16]. Other factors found to influence the level of accrual accounting adoption are top management support, adequate training program and quality of information technology [17]. Ahn et al found that accrual accounting was motivated by elements including a local financial scandal, the civil society group support and the administrators' ambitions and ideas [18]. However, Kobayashi et al. suggest that the institutional role when combined with sociopolitical role is more likely to have greater influence to the accrual accounting adoption [19]. Researchers in Thailand and Italy, on the other hand, found that there are several significant barriers to the implementation of accrual accounting. The barriers are lack of incentive, bureaucratic management culture, lack of manuals and directives and lastly, failure to understand accrual information [20][21].

The adoption of accrual accounting in Malaysia is not fully implemented in cross section departments at the state, statutory bodies and federal level of the government agencies. Muhammad Iqbal [22] found that government should provide more initiatives to attract employees, in addition to the training and seminars towards the successful implementation. This is supported by Rozaidy et al. [23]who concurred that inadequacy in readiness of accounting information system applications such as equipment, software, customization and systems familiarization could also contributed to slow implementation of accrual accounting in government agencies [23].

\subsection{Understanding and awareness on accrual accounting}

Studies from the United Kingdom, Malaysia, Nepal, Republic of Ireland and Italy found out that existing accounting resources are having difficulties in applying accrual accounting techniques. Other than that, lack of understanding of the accrual-based information has also affect the decision making process by non-accountants [24].

On the other hand, the recent study done in fiscal year 2014 and 2015, on the implementation of accrual based accounting by local government in Indonesia revealed that the human resources need to adapt to the changing process from cash to accrual based accounting [25]. Yuliati et al. supported in the research performed in the early years of implementation of 
accrual based accounting since 2015 in Indonesia, technical issues became the obstacle due to staff training and shortages of qualified staff [26]. Interestingly, the same study shows that the application of accrual accounting has increased in the quality of financial reporting after the implementation at local government in Indonesia [26].

\subsection{Readiness of employee for change in accounting methods}

Resistance to change is one of the barriers of the adoption of accrual accounting [24]. The accounting personnel are demotivated to learn due to its difficulties to be understood. Others resist because they are comfortable with the existing accounting technique. The challenges for change towards accrual accounting includes human resources competency, software and technology capability, accounting policies and standard suitability in the implementation effort [6]. This view is reflected by the Nepalese government employees, where they opiniated that priority should be given to addressing the existing deficiencies in accounting practices, instead of spending time on accrual accounting and accounting standards [12].

A major issue had also been raised concerning the delay by the IPSAB in developing the framework. Views were expressed that the framework would have been introduced prior to the issuance of standards rather than when the standards are fully developed [13].

In recent study conducted in Malaysia towards the selected Accountant General Department (AGD) on the implementation of Accrual Accounting System (AAS) shown a positive acceptance of the change. The research indicated that the top management of AGD have successfully led their accounting employees by having good communication flow during the change process, top management's support and encouragement, training program and employees acknowledge on the benefits of the new system [27].

There are indeed mixed view on adopting accrual accounting across the globe. Whilst the government of the respective countries chose to implement accrual accounting in its operation, issues of understanding, awareness as well as readiness of the accounting staffs to use the accounting method can be seen still haunted to ensure the success of such implementation.

\section{$3 \quad$ Methodology}

To fulfil the objective of the study, a quantitative study in the form a survey has been distributed to 16 state government agencies within the state of Melaka, which is the smallest state in Malaysia. The questionaire is divided into two (2) sections which are section A to discuss the general knowledge of the accounting personnel on accrual accounting whilst the second section, Section B concentrates on gathering the respondents profiles.

Melaka state was chosen as this is the state with the highest number of modified audit report issued by the National Audit department of Malaysia for the last 5 years spanning 2013 
to 2017 as shown in below table. The data is extracted from the National Audit Department website [28].

Table 1. Distribution of Audit Report issued other than Standard Unqualified to the State Government Agencies over 5 years (2013-2017)

\begin{tabular}{|l|c|c|c|c|c|}
\hline \multirow{2}{*}{ State Government } & \multicolumn{3}{c|}{ Types of Audit Opinion } & \multirow{2}{*}{ Total } \\
\cline { 2 - 5 } & $\boldsymbol{U}$ & $\boldsymbol{Q}$ & $\boldsymbol{A}$ & $\boldsymbol{D}$ & $\mathbf{2}$ \\
\hline JOHOR & & 2 & & & $\mathbf{3}$ \\
\hline KEDAH & & 2 & 1 & & $\mathbf{3}$ \\
\hline KELANTAN & & 1 & & 2 & $\mathbf{2 3}$ \\
\hline MELAKA & 7 & 16 & & & $\mathbf{3}$ \\
\hline NEGERI SEMBILAN & 2 & 1 & & & $\mathbf{8}$ \\
\hline PAHANG & 2 & 5 & & 1 & $\mathbf{9}$ \\
\hline PERAK & & 9 & & & $\mathbf{5}$ \\
\hline PERLIS & & 5 & & & $\mathbf{5}$ \\
\hline PULAU PINANG & & 5 & & & $\mathbf{1 1}$ \\
\hline SABAH & & 11 & & & $\mathbf{4}$ \\
\hline SARAWAK & 3 & 1 & & & $\mathbf{1 1}$ \\
\hline SELANGOR & 1 & 10 & & & $\mathbf{6}$ \\
\hline TERENGGANU & 2 & 4 & & & $\mathbf{3}$ \\
\hline TOTAL & $\mathbf{1 7}$ & $\mathbf{7 2}$ & $\mathbf{1}$ & $\mathbf{3}$ \\
\hline
\end{tabular}

Ue: Unqualified with Emphasis of Matters (EOM)

Q: Qualified

A: Adverse

D: Disclaimer

\section{$4 \quad$ Findings and discussion}

\subsection{Demographic}

A total of 131 questionaires were gathered from 16 government agencies. The accounting officers within each state government responded to the survey ranged from three (3) to 14 people. The government agencies are divided into three (3) which are state government agencies, local government and statutory bodies. The overleaf table summarizes the demographic of the respondents.

Based on Table 2 below, the majority of the respondents are female $(71.8 \%)$, aged between 25 to34 years old (51.1\%), holding Diploma qualification (42\%) and position as supporting group. In terms of the working sector, an almost equal balance of staffs work under either the local government or the statutory bodies. It can be inferred that majority of the staffs holds at least a Diploma qualification as the combined staffs with qualification of Master/Phd, degree and Diploma consist of 84 out of 131 respondents making up $71.8 \%$. An exposure to a Diploma level presumably majoring in Accounting knowledge and skills should have allowed them to be able to prepare sets of accounts in accrual accounting. The only setback may be 
encountered by the staffs is the fact that public sector accounting may not be exposed in detail and only learn in-depth in the local university ' degree study plan. Hence, local university's study plan concentrates on catering skills to prepare set of accounts for private sector. Less attention if paid to prepare the students to this special needs for accounting in public sector. The positive side is however, lays on the fact that the accounting method employed is based on accrual basis. Using this argument, it is believed that staffs should and would be able to apply the knowledge (with proper training) to record and report the accrual accounting within their working setting.

Table 2. Demographic of the respondents

\begin{tabular}{llc}
\hline Items & Distribution & Total (Percentage) \\
\hline Gender & Male & $37(28.2 \%)$ \\
& Female & $94(71.8 \%)$ \\
\hline Age & $<25$ years & $15(11.5 \%)$ \\
& $25-34$ years & $67(51.1 \%)$ \\
& $35-44$ years & $32(24.4 \%)$ \\
& $=>45$ years & $17(13 \%)$ \\
\hline Educational level & Master/PhD & $4(3.1 \%)$ \\
& Degree & $35(26.7 \%)$ \\
& Diploma & $55(42 \%)$ \\
& SPM & $2(1.5 \%)$ \\
& Others & $5(3.8 \%)$ \\
& & \\
\hline Job Positions & Management and & $17(13 \%)$ \\
& Professional & $113(86.3 \%)$ \\
& Supporting Group & $1(0.8 \%)$ \\
& Others & $15(11.5 \%)$ \\
& & $59(45 \%)$ \\
\hline Working sector & State government & $57(43.5 \%)$ \\
& Local government & \\
& Statutory bodies & \\
\hline
\end{tabular}

\subsection{Findings on respondents general knowledge}

Table 3 provides an insight on the knowledge of accrual accounting of the accounting staffs working in the government agencies. Most of respondents (90.8\%) have heard of accrual accounting but only $64.15 \%$ understand what is accrual accounting. Whilst $82.4 \%$ respondents are ready for the change from cash to accrual accounting, a majority of $84.7 \%$ still feel that they need more exercise on the method. Whilst this findings provide us a relief that the staff generally understand the accrual accounting concept, it is also alarming to discover that a quite large number of staffs have not heard of the term $(9.2 \%)$, do not understand how to apply the 
accrual accounting (35.8\%), and not ready for the change from cash to accrual accounting $(17.6 \%)$.

Table 3. General knowledge on accrual accounting

\begin{tabular}{lcc}
\hline Items & Yes (\%) & No (\%) \\
\hline $\begin{array}{l}\text { Respondents have heard } \\
\text { about accrual accounting }\end{array}$ & $119(90.8 \%)$ & $12(9.2 \%)$ \\
\hline $\begin{array}{l}\text { Respondents understand } \\
\text { about accrual accounting }\end{array}$ & $84(64.15 \%)$ & $47(35.85 \%)$ \\
\hline $\begin{array}{l}\text { Respondents ready for the } \\
\text { change from cash to accrual } \\
\text { accounting }\end{array}$ & $108(82.4 \%)$ & $23(17.6 \%)$ \\
\hline $\begin{array}{l}\text { Respondents need more } \\
\text { training on accrual }\end{array}$ & $111(84.7 \%)$ & $20(15.3 \%)$ \\
accounting
\end{tabular}

Furthermore, $15.3 \%$ respondents feel that they still need to be exposed to more accrual accounting. This result may indicate that some of the accounting department staffs bestowed with responsibility to record the accounting process in the government sector is incompetence in applying accrual accounting in their operation. Can this finding implies that they are not fully ready to execute the change from cash accounting to accrual accounting? If this is the case, then it is quite worrying as the accrual accounting method is believed to be the most method taught in universities in the world.

Table 4 overleaf further elaborates this situation by narrowing down the proportion of general knowledge of these accounting staffs according to specific government agencies. It can be observed from Table 4 that the accounting staffs from the local government in general has favourable response to all the four (4) questions posed, whilst respondents from state government has the least percentage on understanding the accrual accounting.

Table 4. General knowledge on accrual accounting by categories of government agencies

\begin{tabular}{l|cc|cc|cc}
\hline \multirow{2}{*}{ Items } & \multicolumn{2}{|c|}{ State government } & \multicolumn{2}{c|}{ Local government } & \multicolumn{2}{c}{ Statutory bodies } \\
\cline { 2 - 7 } & Yes (\%) & No (\%) & Yes (\%) & No (\%) & Yes (\%) & No (\%) \\
\hline $\begin{array}{l}\text { Respondents have heard } \\
\text { about accrual accounting }\end{array}$ & $12(80 \%)$ & $3(20 \%)$ & $57(96.6 \%)$ & $2(3.4 \%)$ & $50(87.7 \%)$ & $7(12.3 \%)$ \\
\hline $\begin{array}{l}\text { Respondents understand } \\
\text { about accrual accounting }\end{array}$ & $8(53.3 \%)$ & $7(46.7 \%)$ & $43(72.9 \%)$ & $16(27.1 \%)$ & $33(63.2 \%)$ & $24(26.8 \%)$ \\
\hline $\begin{array}{l}\text { Respondents ready for the } \\
\text { change from cash to accrual } \\
\text { accounting }\end{array}$ & $12(80 \%)$ & $3(20 \%)$ & $48(81.4 \%)$ & $11(18.6 \%)$ & $48(84.2 \%)$ & $9(15.8 \%)$ \\
\hline $\begin{array}{l}\text { Respondents need more } \\
\text { training on accrual } \\
\text { accounting }\end{array}$ & $11(73.3 \%)$ & $4(26.7 \%)$ & $54(91.5 \%)$ & $5(8.5 \%)$ & $46(80.7 \%)$ & $11(19.3 \%)$ \\
\hline
\end{tabular}


Table 5 below further elaborates the general knowledge on accrual accounting by job positions. Interestingly, the results revealed that the accounting staffs from the support and other positions group have a slightly higher Yes response for three (3) questions posed than those in the position of management and professionals. The same staffs from the support system, however, has a lower Yes response on understanding the accrual accounting i.e. $62.3 \%$ as compared to the management and professional staffs $(76.5 \%)$. This may be a favourable findings as even though the support staff do not really understand the concept of accrual accounting, they are ready to change to the new accounting and willing to have more training on the subject matter.

Table 5. General knowledge on accrual accounting by categories of job positions

\begin{tabular}{|c|c|c|c|c|c|c|}
\hline \multirow[t]{2}{*}{ Items } & \multicolumn{2}{|c|}{$\begin{array}{c}\text { Management \& } \\
\text { Professionals }\end{array}$} & \multicolumn{2}{|c|}{ Support staffs \& others } & \multicolumn{2}{|c|}{ Total } \\
\hline & Yes $(\%)$ & No $(\%)$ & Yes $(\%)$ & No $(\%)$ & Yes $(\%)$ & No $(\%)$ \\
\hline $\begin{array}{l}\text { Respondents have heard } \\
\text { about accrual accounting }\end{array}$ & $15(88.2 \%)$ & $2(11.8 \%)$ & $104(91.2 \%)$ & $10(9.8 \%)$ & $119(90.8 \%)$ & $12(9.2 \%)$ \\
\hline $\begin{array}{l}\text { Respondents understand } \\
\text { about accrual accounting }\end{array}$ & $13(76.5 \%)$ & $4(23.5 \%)$ & $71(62.3 \%)$ & $43(37.7 \%)$ & $84(64.1 \%)$ & $47(35.9 \%)$ \\
\hline $\begin{array}{l}\text { Respondents ready for the } \\
\text { change from cash to accrual } \\
\text { accounting }\end{array}$ & $14(82.3 \%)$ & $3(17.7 \%)$ & $94(82.5 \%)$ & $20(17.5 \%)$ & $108(82.4 \%)$ & $23(17.6 \%)$ \\
\hline $\begin{array}{l}\text { Respondents need more } \\
\text { training on accrual } \\
\text { accounting }\end{array}$ & $14(82.3 \%)$ & $3(17.7 \%)$ & $97(85.1 \%)$ & $17(14.9 \%)$ & $111(84.7 \%)$ & $20(15.3 \%)$ \\
\hline
\end{tabular}

Table 6 above shows the general knowledge on accrual accounting by educational level of the respondents. As expected, the staffs from the professional and management holding at least a degree in Accounting provide a higher Yes response for three (3) questions posed in terms of whether they have heard about accrual accounting, understand the accrual accounting and ready for the change from cash to accrual accounting. These answers do corresponds with this group responds to the last question on whether they need more training on the accrual accounting $(79.5 \%)$. This can be inferred as a positive feedback from the much higher position staff as they hold the managerial position and need to direct their supporting staffs to the new changes in the accounting method. Their readiness to change with less training may indicate readiness of the respective government agencies in general. 
Table 6. General knowledge on accrual accounting by categories Educational level

\begin{tabular}{l|cc|cc|cc}
\hline \multirow{2}{*}{ Items } & \multicolumn{2}{|c|}{$\begin{array}{c}\text { Degree/Masters/PhD } \\
\text { (Professional \& } \\
\text { management) }\end{array}$} & $\begin{array}{c}\text { Diploma } \\
\text { (mainly support staff) }\end{array}$ & $\begin{array}{c}\text { Others } \\
\text { (SPM and below) }\end{array}$ \\
\cline { 2 - 6 } & Yes (\%) & No (\%) & Yes (\%) & No (\%) & Yes (\%) & No (\%) \\
\hline $\begin{array}{l}\text { Respondents have heard } \\
\text { about accrual accounting }\end{array}$ & $38(97.4 \%)$ & $1(2.6 \%)$ & $52(94.6 \%)$ & $3(5.4 \%)$ & $31(83.8 \%)$ & $6(16.2 \%)$ \\
\hline $\begin{array}{l}\text { Respondents understand } \\
\text { about accrual accounting }\end{array}$ & $31(79.5 \%)$ & $8(20.5 \%)$ & $38(69.1 \%)$ & $17(30.9 \%)$ & $15(40.5 \%)$ & $22(59.5 \%)$ \\
\hline $\begin{array}{l}\text { Respondents ready for the } \\
\text { change from cash to accrual } \\
\text { accounting }\end{array}$ & $35(89.7 \%)$ & $4(10.3 \%)$ & $43(78.2 \%)$ & $12(21.8 \%)$ & $30(81.1 \%)$ & $7(18.9 \%)$ \\
\hline $\begin{array}{l}\text { Respondents need more } \\
\text { training on accrual } \\
\text { accounting }\end{array}$ & $31(79.5 \%)$ & $8(20.5 \%)$ & $49(89.1 \%)$ & $6(10.9 \%)$ & $31(83.8 \%)$ & $6(16.2 \%)$ \\
\hline
\end{tabular}

Although this preliminary study focuses only on one state in Malaysia, the results of the study may imply the overall state of understandability of accrual accounting impementation within the government agencies throughout Malaysia. The Malaysian government agencies need to equip their accounting staffs with the necessary training and skills before accrual accounting can successfully be implemented in the government agencies.

\section{Conclusion}

This case study envisages to obtain feedback on the change in the accounting method from cash accounting to accrual accounting basis by the Accounting staffs within the government agencies. The respondents were 131 Accounting staffs within 16 government agencies of the smallest state in Malaysia. Mixed responses have been received from the different level of positions for the change of the method as well as their understanding over the new accounting method. Although in general, positive feedback have been received on the readiness and willingness of the staffs to embrace the change, attention should be focused in ensuring they are equip with enough knowledge to actually apply the new accounting method in recording and reporting. Mistakes in interpreting the method would lead to wrong reporting of the accounting of the respective government agencies. Nevertheless, the result of the study may assist the state authority to identify the lacking accounting skills within their Accounting employees. As the government agencies are seen as bodies responsibled to manage and utilize public funds effectively, transparent account reporting is certainly a public concern. Public would certainly demand skilled Accounting staffs hired to manage the public fund and record the accounting transactions diligently. 


\section{Acknowledgements}

The researchers would like express their gratitude to the state government agencies who were willing to take part in the survey. The survey was conducted with the aim to assist them to better manage their organizations.

\section{References}

[1] R. Rauf, F.A., Yusoff, H., Yatim, N., Poobalan, U.R., Salleh, S.C., \& Othman, Public sector accounting: Malaysian Context, 4th ed. Kuala Lumpur: Pearson Malaysia Sdn Bhd, 2015.

[2] Z. Saleh, C. R. Isa, and H. A. Hasan, "Accrual accounting: Change and managing change," IPN J. Res. Pract. Public Sect. Account. Manag., vol. 2, no. Special Issue, pp. 41-52, 2012.

[3] PWC, "Global survey on accounting and financial reporting by central governments (2 nd edition)," 2015.

[4] M. . Baker R.O.N \& Rennie, "Forces leading to the adoption of accrual accounting by the Canadian federal government: An institutional perspective," Can. Account. Perspect., vol. 5, no. 1, pp. 83-112, 2006.

[5] A. T. Tudor and A. Mutiu, "Cash versus Accrual Accounting in Public Sector," Research gate, 2006. [Online]. Available: http://ssrn.com.

[6] N. Shawallizayusof and H. Jaafar, "The Implementation of Accrual - Based Accounting in Malaysian Public Sector : Opportunities and Challenges," vol. 11, no. 1, pp. 49-62, 2018.

[7] R. Omar, N. A. Amran, and N. Aripin, "Adoption of accrual accounting in local authorities of Kedah Darul Aman," Universiti Utara Malaysia, 2005.

[8] A. H. Azmi and N. Mohamed, "Readiness of Malaysian Public Sector Employees in Moving towards Accrual Accounting for Improve Accountability: The Case of Ministry of Education (MOE)," Procedia - Soc. Behav. Sci., vol. 164, no. August, pp. 106-111, 2014.

[9] M. Gomez, "Improving public sector finance," Accountants Today, vol. 26, no. 1, pp. 12-15, 2013.

[10] S. Ismail, S. A. Siraj, and S. Baharim, "Implementation of accrual accounting by Malaysian federal government: Are the accountants ready?," J. Account. Organ. Chang., vol. 14, no. 2, pp. 234-247, 2018.

[11] J. . Xavier, "It merits out favour," New Straits Times, p. 1, 08-Nov-2018.

[12] D. S. Showater, "Why governments should invest in Accrual Accounting," J. Gov. Financ. Manag., pp. 10-11, 2018

[13] Sylvia, E. G. Sukoharsono, Y. W. Prihatiningtias, and Roekhuddin, "Public interest and accrual accounting: are they aligned?," J. Account. Organ. Chang., vol. 14, no. 4, pp. 366-380, 2018.

[14] K. Mbelwa, Latifa; Adhikari, Pawan; Shahadat, "An examination of the institutional and decisionusefulness factors in the implementation of accrual accounting reforms in the public sector of," J. Account. Emerg. Econ., vol. 9, no. 3, pp. 335-365, 2019.

[15] P. Adhikari, C. Kuruppu, and S. Matilal, "Dissemination and institutionalization of public sector accounting reforms in less developed countries: A comparative study of the Nepalese and Sri Lankan central governments," Account. Forum, vol. 37, no. 3, pp. 213-230, 2013.

[16] K. Aswar and S. Z. Saidin, "Accrual Accounting Adoption In Java Municipalities: An Empirical Investigation," Int. J. Bus. Econ. Sci. Appl. Res., vol. 11, no. 3, pp. 24-30, 2018.

[17] P. D. Ahn, K. Jacobs, D. W. Lim, and K. Moon, "Beyond Self-Evident: Recognising the Problematic Political Context of Accrual Accounting Adoption in South Korea," Financ. Account. Manag., vol. 30, no. 1, pp. 25-48, 2014.

[18] M. Kobayashi, K. Yamamoto, and K. Ishikawa, "The Usefulness of Accrual Information in Nonmandatory Environments: The Case of Japanese Local Government," Aust. Account. Rev., vol. 26, no. 2, pp. 153-161, 2016.

[19] O. Nakmahachalasint and K. Narktabtee, "Implementation of accrual accounting in Thailand's central government," Public Money Manag., vol. 39, no. 2, pp. 139-147, 2019. 
[20] S. Gigli and L. Mariani, "Lost in the transition from cash to accrual accounting: Assessing the knowledge gaps in Italian public universities," Int. J. Public Sect. Manag., vol. 31, no. 7, pp. 811826, 2018.

[21] S. H. Shuid, S. A. Basri, and A. S. A. Zazili, "Challenges in the adoption of MPSAS/IPSASS/ACCRUAL accounting in Malaysia and other countries," Religacion, vol. 4, no. 17 , pp. 702-709, 2019.

[22] Muhammad Iqbal Mohamed Azhari, "The Preparedness of the Accountants From the Malaysian Accountants Department in Moving Towards Accruals Accounting," Universiti Teknologi Mara, 2013.

[23] R. Mahadia, R. Noordin, R. Mail, and K. Sariman, "Accrual Accounting in Malaysia: What We Should Learn from Others," Malaysian J. Bus. Econ., vol. 1, no. 2, pp. 63-76, 2020.

[24] P. Adhikari and L. Gårseth-Nesbakk, "Implementing public sector accruals in OECD member states: Major issues and challenges," Account. Forum, vol. 40, no. 2, pp. 125-142, 2016.

[25] R. R. Gamayuni, "the Initial Implementation of Accrual Based Accounting, the Effect on Performance and Financial Reporting Quality At Local Governments in Indonesia,” Ekspansi J. Ekon. Keuangan, Perbank. dan Akunt., vol. 11, no. 1, p. 13, 2019.

[26] R. Yuliati, Y. Yuliansyah, and Y. E. Adelina, "The implementation of accrual basis accounting by Indonesia's local governments," Int. Rev. Public Adm., vol. 24, no. 2, pp. 67-80, 2019.

[27] E. Mosuin, T. Z. T. Mat, E. K. Ghani, A. Alzeban, and A. Gunardi, “Accountants' acceptance of accrual accounting systems in the public sector and its influence on motivation, satisfaction and performance," Manag. Sci. Lett., vol. 9, no. 5, pp. 695-712, 2019.

[28] The National Audit Department, "The State Governments' Financial Statements," Malaysian National Audit Department, 2019. [Online]. Available: http://www.audit.gov.my/index.php/ennancial-statement. [Accessed: 20-Feb-2019]. 